\title{
Ethics for Beginners
}

\section{Dr. Marilyn A. Dyrud, Oregon Institute of Technology}

Marilyn Dyrud is a full professor in the Communication Department at Oregon Institute of Technology and regularly teaches classes in business and technical writing, public speaking, rhetoric, and ethics; she is part of the faculty team for the Civil Engineering Department's integrated senior project.

She is active in ASEE as a regular presenter, moderator, and paper reviewer; she has also served as her campus' representative for 17 years, as chair of the Pacific Northwest Section, and as section newsletter editor. She was named an ASEE Fellow in 2008. Currently, she is on two division boards, Engineering Technology and Engineering Ethics, and has served as Zone IV chair. In 2010, she received the McGraw Award, and in 2013, the Berger Award.

In addition to ASEE, Marilyn is active in the Association for Practical and Professional Ethics as proceedings editor and the Association for Business Communication, serving on the editorial boards of two journals and editing a teaching section for ABC's pedagogical journal.

\section{Dr. Julie E. Sharp, Vanderbilt University}

Julie E. Sharp, Professor of the Practice of Technical Communications, has taught written and oral communication courses in the Vanderbilt University Engineering School for over 25 years. She designs and instructs the technical communication portion of combined engineering lab/technical communication courses, a technical communication course for engineering majors (serving as course coordinator) and most recently a course in engineering professional development, the first of its kind in the Vanderbilt School of Engineering. She has published numerous articles and presented successful workshops on communication in engineering courses, teaching, ethics, and learning styles. As a consultant, she has edited and written documents and conducted workshops for educators, industry, and professional organizations.

She was awarded both a 2013 and 2012 Apex Award of Excellence in Education and Training Writing, sponsored by Communication Concepts Inc., for her 2013 and 2012 ASEE papers. In 2004, she earned the ASEE Southeastern Section's Thomas C. Evans Award for "The Most Outstanding Paper Pertaining to Engineering Education." Active as a presenter and moderator at ASEE and FIE and a reviewer for several journals, she is a member of the Society for Technical Communication, (past president of the Middle Tennessee Chapter), the Association of Professional Communication Consultants, and the National Council of Teachers of English. Dr. Sharp earned the Ph.D. in English Education, M.A. in English, and M.A.T. in English from Vanderbilt University; and the B.A. in English from Belhaven University. 


\section{Ethics for Beginners}

\section{Introduction}

Consider this scenario:

For several years, you have been responsible for teaching the "Introduction to Engineering" class for new students in your department. This year, your department chair decides that integrating ethics would be a stellar idea, so that students can begin their academic careers with a firm understanding of behavioral expectations in their chosen field.

Since you have only a vague knowledge of ethics, you hop on Google and start searching. To your dismay, you find 156 million websites on the general topic of ethics. So you narrow it down to "engineering ethics," and Google spits out another enormous number: $8,333,000$. This is getting discouraging. Finally, you try "teaching engineering ethics," which yields a mere 1,840,000. Even Google Scholar gives you 17,000 possibilities.

A sense of panic begins burbling up: what do you do?

Since the "new" ABET criteria appeared over a decade ago, more engineering and technology programs have incorporated ethics components in response to Criterion $3 \mathrm{f}$, requiring that students display "an understanding of professional and ethical responsibility." "For new or even seasoned educators, however, this is easier said than done.

As one of the ancient fields of study, ethics can be quite intimidating, especially the complicated vocabulary and the enormous body of literature. And for those more mathematically oriented, the ambiguity of ethical decision-making may prove to be puzzling.

Written by two seasoned educators who have integrated ethics in their classes and/or taught ethics classes for a combined 40 years, this paper offers advice for those new to the field who wish to include ethics components in technical courses. Based on discussions with colleagues, the paper examines the following areas identified by faculty new to ethics as critical for preparation: finding resources, acquainting students with professionalism, introducing professional codes, and using a case-based approach.

Providing students with a rationale for including ethics in a technical course, beyond addressing the ABET criterion, is important; Michael Davis, who has published widely in the field of engineering ethics, explains that ethics is a vital aspect of engineering, "Knowing engineering ethics is as much a part of knowing how to engineer as knowing how to calculate stress or design a circuit ... insofar as engineering is a profession, knowing how to calculate stress or design a circuit is in part knowing what the profession allows, forbids, or requires." "In other words, including the study of ethics in engineering or technology courses is not gratuitous but an integral part of the field. 


\section{Resources}

As noted above, the amount of Internet information available on engineering ethics is vast, as is the scholarly literature. While a degree in philosophy is not required to teach ethics, selfpreparation is necessary, as ethical decisions are not really intuitive and subjective. Interested instructors will find very helpful information via several online engineering ethics centers, such as the Center for the Study of the Professions at Illinois Institute of Technology (http://www.iit.edu/research/ profiles/csep.shtml), the Murdough Center for Engineering Professionalism and the National Institute of Engineering Ethics at Texas Tech (http://www.niee.org/murdoughCenter/index.php), the Online Center for Engineering and Science (http://www.onlineethics.org/), and The Ethics Center at Texas A\&M University (http://ethics.tamu.edu/). In addition, the Board of Ethical Review of the National Society of Professional Engineers (http://www.nspe.org/resources/ethics/board-ethical-review) offers descriptions of real cases involving professional misconduct and recounts the board's deliberations.

Engineering ethics textbooks also offer a useful starting point. In particular, Harris, Pritchard, and Rabins's Engineering Ethics, Concepts and Cases ${ }^{3}$ and Martin and Schinzinger's Ethics and Engineering ${ }^{4}$ are valuable orientation sources for teachers new to ethics.

Reviewing information on micro- and macroethics can also help an instructor to arrange the ethical components of a technical course. Briefly, microethics involves actions of individual engineers whereas macroethics deals with social matters. ${ }^{5}$ Since engineering has "an inherent (and unavoidable) impact on society," "examining that area is crucial. In fact, Conlon and Zandvoort indicate the need for increased emphasis on the social dimensions of engineering, explaining that "the exclusive focus is on engineers as individual agents and the broader context in which they do their work is ignored"7 to the detriment of engineering education in general. Including the societal repercussions of engineering also addresses ABET Criterion $3 \mathrm{~h}$, "the broad education necessary to understand the impact of engineering solutions in a global, economic, environmental, and societal context."1

A final recommendation is for instructors to peruse the "ethics across the curriculum" materials available at IIT's ethics center. For many years, Vivian Weil and Michael Davis have offered a valuable NSF-sponsored workshop on integrating ethics. Just examining the "post-workshop materials" section, for example, yields a gold mine of practical ideas for ethics integration, easily transferrable between academic fields. ${ }^{8}$

\section{Students and Professionalism}

Involving students in a study of engineering ethics means introducing the concept of professionalism since engineering ethics falls squarely under the purview of professional ethics. Instructors should be "emphasizing the ethical obligations of engineering as a profession."

Student concepts of a profession/professional, however, may be decidedly different from those definitions in the rather substantial literature related to the subject. Asking a freshman student what a professional is may yield a surprisingly common response: anyone who makes a living 
wage and is good at what s/he does. This is perhaps due to the way that word is used in the US; a brief sweep of the Internet shows hobbies-evolved-into-jobs that have assumed the term "professional," possibly as a way to elevate the stature of that occupation: fly fishing, belly dancing, blogging, etc. ${ }^{10}$

In the field of engineering, however (or teaching or law or medicine, for that matter), "professional" connotes something much different from simply earning money: it involves responsibility, expertise, reasoned judgment honed by experience and a standard of conduct, autonomy, a lifelong commitment to the field that includes an obligation for continuous education, a passion for what one does, and a sense of service to society. ${ }^{11,12,13}$ Callahan suggests the term "calling" to describe a professional; a deep-seated, lifelong desire to fully engage in a given area. ${ }^{14}$ Introducing professional ethics codes is an effective approach for reinforcing the concept of professionalism.

\section{Professional Codes}

Codes define conduct in a given field. Acquainting students with the provisions of their field's particular code is a convenient way to have them recognize their future career obligations. In mainline engineering fields, the codes share the Fundamental Principles and Fundamental Canons. Some, but not all, engineering professional organizations include a detailed section that interprets the canons, with reference to that particular engineering specialty. Engineering codes tend to be more general compared to those of other professions; the AMA's Code of Medical Ethics, for example, is a book, as it details modes of conduct in specific situations. ${ }^{15}$

If students learn nothing else from studying their code of ethics, they should understand that safeguarding the public welfare is the primary concern of an engineer and betraying that trust is a serious matter. A Jack D. Gillum, engineer of record for the Hyatt Regency walkways project in Kansas City, noted 19 years after that tragedy, "Responsibility and ethics go hand in hand. All engineers or engineering candidates must learn the enormous responsibility they assume to earn the right to be called Engineer of Record or Engineer in Responsible Charge."16

Codes are controversial; not all ethicists agree that they are good. In fact, philosopher John Ladd, who has written widely on such topics as professional loyalty, suggests that codes can have "mischievous side effects,"17 and Stieb points to "a certain lack of transparency, clarity, and accountability." ${ }^{18}$ Nevertheless, as Harris, Pritchard, and Rabins explain, they do serve the useful purpose of "articulat[ing] shared standards" among professionals, ${ }^{3}$ and, according to Colby and Sullivan, codes can assist instructors by "provid[ing] valuable framework for thinking about the goals of educating for engineering ethics and professional responsibility."19

Michael Loui, computer engineer turned ethicist, has noted that studying engineering ethics can help students "develop their identities as professionals." In a survey conducted at the end of the semester, his students identified discussions of case studies and exposure to multiple perspectives as the most influential elements in a required engineering ethics course. ${ }^{20}$ Loui's students are not alone; several commentaries on ethics in engineering education have cited cases as the most common method for teaching engineering ethics. ${ }^{21,22,23}$ 


\section{Case-Based Approach}

For those new to teaching ethics, cases are an engaging way to involve students in applying ethical decision-making to real-life or simulated, realistic examples. Passow recommends framing technical work within realistic "decision-making situations" to help students develop professional skills required by ABET, such as ethical problem solving, along with technical skills. ${ }^{24}$ Real instances are preferable to confected textbook cases as reality-based situations are messy and may entail considerable complexity with no clear-cut "right" solution.

\section{Benefits}

Cases provide a practical way for students to be "hands-on" in analyzing situations they may face in the workforce. A recent study concluded that students' knowledge of ethics is "surprisingly low." ${ }^{25}$ By using cases, instructors can enhance students' problem-solving and analytical skills and improve their abilities to make decisions and deal with ambiguities. ${ }^{26}$ And because engineering students tend to enjoy the challenge of solving problems, they can readily engage in situations that pose ethics issues. Analyzing cases allows more students to enter the discussion than does a lecture, and working in small groups to analyze and discuss an ethics case can amplify student perceptions of how ethical and professional issues intertwine. Furthermore, cases can deepen students' understanding that various, valid perspectives on an issue are possible — what Pat Werhane has dubbed the "moral imagination"27_and that a complicated issue can be solved. In addition, the very fact that an instructor brings an ethical issue into the classroom emphasizes the importance of ethics and may heighten students' ethical awareness. ${ }^{28}$

The National Center for Case Study Teaching in Science confirmed many of these benefits in a study involving primarily university professors who had taken the center's training workshops on case methodology. After incorporating this method, professors were asked how students benefited. More than $78 \%$ thought that students improved in critical thinking skills, learning, and participation. Some specific areas included being "better able to view an issue from multiple perspectives," gaining "a deeper understanding of concepts," showing "a better grasp of the practical application of core course concepts," "strengthen[ing] communication skills," and becoming "more engaged in class." Over 60\% reported that students "increased their discussion of ethical issues.", 29

\section{Drawbacks}

The case method does have some drawbacks. For example, the emphasis is usually on microethics rather than macro, which some ethicists see as neglecting important issues. As Stephan states, “. . . even if everyone makes good microethical decisions, you can have systems and legal frameworks and large-scale institutions in place which nevertheless cause harm and need to be addressed ...., ,30

Other drawbacks concern student reactions. For example, instructors may encounter resistance to discussions about an issue lacking a clearcut answer or solution because some students have difficulty dealing with ambiguity and vagueness. They also may think discussion is a waste of 
time and/or dislike working in groups. Furthermore, the case study method may create anxiety because the "learning is messier" than with a more traditional method. ${ }^{31}$

Time is also a factor. That is, an instructor must allow adequate time to prepare for presenting a case that generates meaningful class dialogue. The amount may vary, but it is more time consuming than preparing a lecture. In addition, including a case analysis in a content class may take time away from dealing with another topic. An instructor whose goal is content coverage may find this a challenge. Both the instructor and the students may need time to master the case study technique, so they may consider the first few instances to be negative experiences and become discouraged. Some instructors may also be uncomfortable leading open-ended discussions about ethics topics because they lose a certain amount of classroom control. ${ }^{32}$

\section{Selecting Cases}

As one source explains, case studies are "descriptions of real situations that provide a context for engineers and others to explore problems." ${ }^{\prime 3}$ Effective cases share these characteristics:

1. They are realistic, either an actual occurrence or a simulated, possible one.

2. They usually do not have an obvious solution.

3. They tell a story with one or more aspects of conflict.

4. They tell a story to which students can relate or have empathy with the situation or characters.

5. They can be either simple or complex. A complex case contains a large amount of information with data perhaps in charts and graphs and may not be appropriate for a beginner ethics teacher. ${ }^{34}$

Some experienced instructors use "layered" cases, where they start with a simple conflict and then add more complicating details, ${ }^{35}$ while others recommend starting with relatively simple cases. Complex cases may require research outside of class and several class periods to analyze and discuss. For the instructor new to teaching ethics cases, starting with a complex case that requires considerable research is probably not a good idea. ${ }^{32}$

When selecting a case, the instructor should keep these characteristics in mind :

1. The case should be appropriate for the students; it should match the students' skill level or knowledge of the course topic. For example, mechanical engineering seniors may be more experienced with certain discipline-specific subject matter than first-year students and could handle a case requiring more advanced knowledge. Furthermore, each student should be able to relate to the issue so that no one person or small group is disenfranchised. ${ }^{36,37}$

2. A case should be complex enough to engage students in problem solving. Even if the case is simple, it should be complex enough to generate group discussion and alternative solutions to the problem posed. It should be interesting to students and provide a challenge that they want to tackle. ${ }^{36}$ 
3. It should be broad enough to allow for more than one right answer and to allow for more than one viewpoint. $^{36}$

4. It should be suitable for a time limit of perhaps one or two class periods. ${ }^{36}$

5. It should be apparently doable in complexity and length. If students think the case is too involved, they may resist working on it. One instructor says her students lose interest if the explanatory material is over three pages. ${ }^{36}$ However, it should not be overly simplified or "thin.",38

6. It should allow the instructor to prepare without feeling overloaded. ${ }^{37}$

Basing cases on real-life situations is an effective selection method. For example, an instructor could use experiences with plagiarism to craft a narrative about an issue a teaching assistant has with a fictitious student. The instructor could develop handouts with short articles or article excerpts and the student's use of these sources. Students would discuss in groups to determine if the person plagiarized and how to resolve the issue. ${ }^{34}$ This example would give students a chance to determine the differences between what one source has called "malicious" and "nonmalicious" plagiarism. ${ }^{39}$ This case is simple enough that students can discuss and analyze within one or two class periods and yet complex enough to allow for considering different options. This example is suitable for any class because plagiarism is a common concern. It would be especially appropriate for a technical communication course concerned with identifying and avoiding plagiarism.

Another example is one appropriate for a class dealing with interviewing skills. Students would discuss how to negotiate a job offer and to avoid unethical handling of several job offers. For example, the scenario might concern a student who accepts a job and then receives a better offer from a preferred company. Students would conduct a problem analysis to find an ethical way to resolve this issue. ${ }^{40}$ Instructors interested in this topic may want to use the example "The Joy of Being Wanted" from the Murdough Center's website. ${ }^{41}$ Although this case appears on numerous websites, the Murdough Center site offers, in addition to a well-written case, various short responses and survey results about the case.

Healy cautions against designing a "thin" case, one that omits needed information or "assumes too much." Such cases may be "short, easily posed, and attention-getting. . .." While some thin cases may be dramatic and attract student interest, they are atypical of what graduates can expect in daily life. Thin cases do not deal with issues stemming from "partiality," a typical human trait in ordinary life where someone is partial to one or more persons. Thin cases also usually deal with win-lose decisions. This type of decision does not prepare students for trying to find winning solutions for all those concerned. ${ }^{38}$

\section{Method for Case Analysis}

One helpful technique for analyzing an ethics case is Michael Davis' format for resolving ethical issues. ${ }^{42}$ Davis' "Seven Step Method for Ethical Decision Making" can be found in several versions on the Illinois Institute for Technology Center website with variations mostly occurring 
in the wording of items 1 and $3 .^{43,44}$ Regardless of the version, the system is quite helpful for faculty preparing to guide a discussion and for students analyzing an ethical issue. Figure 1 is slightly adapted from the 2013 version.

1. State problem ("What is the main issue at stake in this case?")

2. Gather and assess relevant facts (address the non-ethical issues raised within the case and make appropriate assumptions based on available information)

3. Identify stakeholders (generate a list of all possible individuals, groups, or entities who will be affected by the decisions to be made)

4. Develop list of options (be imaginative; try to avoid "yes/no" dilemma; focus on whom to go to, what to say)

5. Test options, using the following:

- Harm: Does this option do less harm than any alternative?

- Publicity: Would I want my choice of this option published in the newspaper?

- Defensibility: Could I defend my choice of this option before a Congressional committee or committee of my peers?

- Reversibility: Would I still think the choice of this option good if I were one of those adversely affected by it?

- Virtue: What would I become if I choose this option often?

- Colleague: What do my colleagues say when I describe my problem and suggest this option as my solution?

- Professional: What might my profession's ethics committee say about this option?

- Organization: What does the company's ethics officer or legal counsel say about this?

6. Make a tentative choice based on steps 1-5: Did you solve the problem?

7. Make a final choice (after review steps $1-60$, act, and then ask:

- What could make it less likely you would have to make such a decision again?

- What precautions can you take as an individual (announce policy on question, change job, etc.)?

- What can you do to have more support next time (e.g., seek future allies on this issue)?

- What can you do to change larger society (e.g. work for a new statute or EPA regulation)?

Figure 1. An ethical decision-making strategy ${ }^{42}$ 
Instructors can give students worksheets with these items to complete in groups during class or in individual or group assignments for homework.

This paper has previously mentioned several useful resources. Even these few, however, contain a wealth of information that may seem initially daunting. For the new instructor, three websites are especially helpful. Reading several cases with attached responses from the Murdough Center website or the NSPE's Board of Ethical Review ${ }^{45,46}$ provides a solid background and examples of various approaches or viewpoints. Both have clearly written, concise cases and a variety of responses without an overload of information. The National Academy of Engineering Online Ethics Center website also has some 32 cases, all involving potential on-the-job engineering situations that require ethical reasoning. ${ }^{47}$

\section{Guiding Case Discussions}

Before discussing the case in class, instructors should prepare students to help the discussion progress smoothly. For example, they can set and announce discussion guidelines, such as showing respect for all contributions and questions. ${ }^{34}$ Explaining what to expect in an ethics discussion may help students avoid pitfalls, such as discouragement with ambiguity and conflicting viewpoints.

Ladenson recommends that instructors guide the discussion without dominating it, arguing, or lecturing. He also warns that the discussion may not cover every aspect of the case thoroughly and, if so, one should "just accept" that outcome. It is helpful if the instructor responds to student comments, ${ }^{28}$ although Valenchik recommends that instructors should not give in to the "professorial urge to respond to every student statement." 32 Asking questions will help keep the discussion on track, clarify any confusing statements, and emphasize especially cogent comments. ${ }^{28}$ After the discussion, the instructor can summarize the major outcomes of the discussion, reflect on relevant comments, and ask for student feedback on the discussion process itself. ${ }^{32}$ Using the "one-minute paper" technique, in which students write questions, comments, or concerns on a note card, can provide immediate feedback and help instructors develop followup sessions that focus on student remarks.

\section{Integrating Ethical Theory}

Using applied ethics, rather than a moral philosophy approach, suggests a decreased emphasis on ethical theory as a problem-solving strategy. In a typical ethics course, students learn about moral theories, such as utilitarianism, and then apply that theory to the problem at hand. While this approach is standard in stand-alone philosophy courses, it can result in a number of problems for students who are exposed to ethics in a technical class: primarily, as Lawlor notes, "this could lead to a particularly crude form of relativism, where students take the answers to ethical questions to be relative to moral theories, such that they think the idea is to pick a moral theory and then simply follow it to its conclusions." 48 In a technical course that integrates ethics, however, the opposite occurs: the appropriate theory arises from the case.

For example, in the 1995 collapse of the Sampoong department store in Seoul, South Korea, 500 people died as the building pancaked down in a mere 20 seconds. Hundreds more were injured, 
and the building owner, engineering staff, and assorted public officials received jail sentences for demonstrated negligence, bribery, and several other offenses. ${ }^{49}$ Ethically speaking, these people were guilty of more than illegality; they clearly showed a lack of engineering responsibility, a contempt for the general public by building an unsafe building and bribing inspectors, and a definite blindness to the fundamental precept of utilitarianism: they did not make decisions that resulted in the "greatest good for the greatest number." In fact, the opposite occurred.

\section{Conclusions}

Including ethics in engineering and technology classes is an imperative, not a choice. Instructors will not only satisfy ABET criteria, but, more importantly, students will learn significant information relating to their professional lives, offering diverse perspectives on their chosen careers: seen through an ethics prism, the world is a different place.

As this paper has noted, a number of resources, specifically geared for integrating ethics into technical classes, are available to help instructors develop classroom activities and assignments that result in animated class discussions. Students can learn that the moral imagination allows for various perspectives, that problems can have multiple solutions, and that ethical analysis is similar to the engineering problem-solving method. Furthermore, integrating ethics supports Michael Davis' cogent observations that ethics and engineering have a symbiotic relationship, that thinking like an engineer means thinking ethically about responsibilities and repercussions of decisions, and that comprehending engineering ethics is "understanding engineering as a profession."

\section{References}

1. ABET. (2014). Criteria for accrediting engineering programs, 2015-2016. Retrieved from http://www.abet.org/ eac-criteria-2015-

2. Davis, M. (1999). Teaching ethics across the engineering curriculum. Retrieved from http://onlineethics.org/ CMS/edu/instructessays/curriculum.aspx

3. Harris, C. E., Pritchard, M. S., \& Rabins, M. J. (2014). Engineering ethics: Concepts and cases (5th ed.). New York: Wadsworth.

4. Martin, M. W., \& Schinzinger, R. (2004). Ethics and engineering (3rd ed.). New York: McGraw-Hill.

5. Herkert, J., Wetmore, J., Canary, H., \& Ellison, K. (2009). Integrating microethics and macroethics in graduate science and engineering education: Developing instructional models. ASEE Annual Conference Proceedings. Retrieved from http://archive.cspo.org/projects/eese-daim/publications/ASEE-2009-paper.pdf

6. Nichols, S. P., \& Weldon, W. F. (n.d.). Professional responsibility: The role of the engineering in society. Retrieved from http://www.me.utexas.edu/ srdesign/paper/

7. Conlon, E., \& Zandvoort, H. (2011). Broadening ethics teaching in engineering: Beyond the individualistic approach. Science \& Engineering Ethics, 17, 217-232.

8. Center for the Study of Ethics in the Professions. (2014). Post-workshop materials. Retrieved from http://ethics.iit.edu/node/87

9. Lynch, W. T., \& Kline, R. (2000). Engineering practice and engineering ethics. Society, Technology \& Human Values, 25, 195-225.

10. Dyrud, M. A. (2012). Plumbers and professionalism. ASEE Annual Conference Proceedings. Retrieved from http://www.asee.org/public/conferences/8/papers/2939/view

11. Bayles, M. D. (1989). Professional ethics. Belmont, CA: Wadsworth.

12. Kultgen, J. H. (1988). Ethics and professionalism. Philadelphia: University of Pennsylvania. 
13. Lawson, W. D. (2004, January). Professionalism: The golden years. Journal of Professional Issues in Engineering Education and Practice, 130(1), 25-26.

14. Callahan, J. C. (1988). Ethical issues in professional life. New York: Oxford.

15. American Medical Association. (2015). Code of medical ethics. Retrieved from http://www.amaassn.org/ama/pub/physician-resources/medical-ethics/code-medical-ethics.page

16. Gillum, J. D. (2000). Professionalism, responsibility, and engineering ethics. Forensic Engineering, 57-65.

17. Ladd, J. (1991). The quest for a code of professional ethics: An intellectual and moral confusion. In D. G. Johnson (Ed.), Ethical issues in engineering (137-154). Englewood Cliffs, NJ: Prentice Hall.

18. Stieb, J. A. (2011, March). Understanding engineering professionalism: A reflection on the rights of engineers. Science \& Engineering Ethics, 17(1), 149-169.

19. Colby, A., \& Sullivan, W. C. (2008). Ethics teaching in undergraduate engineering education. Journal of Engineering Education, 97(3), 1-12.

20. Loui, M. C. (2005). Ethics and the development of professional identities of engineering students. Journal of Engineering Education, 94(4), 383-390.

21. Zandvoort, H., van de Poel, L., \& Brumsen, M. (2000). Ethics in the engineering curricula: Topics, trends, and challenges for the future. European Journal of Engineering Education, 25(4), 291-302.

22. Bucciarelli, L. (2007, October 7). Ethics and engineering education. Retrieved from http://dspace.mit.edu/ bitstream/handle/1721.1/40284/ethics_20_talk.pdf?sequence=1

23. Abu Hamad, J., Hasanain, M., Abdulwahed, M., \& Al-Ammari, R. (2013). Ethics in engineering education: A literature review. Proceedings of the IEEE Frontiers in Education Conference, 1554-1560.

24. Passow, H. J. (2012, January). Which ABET competencies do engineering graduates find most important in their work? Journal of Engineering Education, 101(1), 95-118.

25. Finelli, C. (2012). An assessment of engineering students' curricular and co-curricular experiences and their ethical development. Journal of Engineering Education, 101(3), 469-494.

26. Using case studies to teach. (n.d.). Retrieved from http://www.bu.edu/ceit/teaching-resources/using-casestudies-to-teach/

27. Werhane, P. E., \& Moriarty, B. (2009). Moral imagination and management decision making. Retrieved from

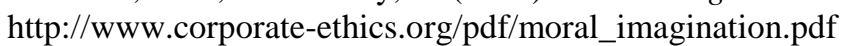

28. Ladenson, R. (2003). Leading case discussions. Retrieved from http://ethics.iit.edu/teaching/leading-casediscussions

29. Faculty perceptions of the benefits of case teaching. (n.d.). Retrieved from http://sciencecases.lib. buffalo.edu/cs/pdfs/Faculty-Perceptions-of-the-Benefits-of-Case-Teaching.pdf

30. Stephan, K. D. (2009, October 5). Microethics, macroethics, and the working engineer. Retrieved from http://engineeringethicsblog.blogspot.com/2009/10/microethics-macroethics-and-working.html

31. Weimer, M. (2009, November 12). Problem-based learning: Benefits and risks. Retrieved from http://www.facultyfocus.com/articles/effective-teaching-strategies/problem-based-learning-benefits-and-risks/

32. Velenchik, A. (n.d.). Teaching with the case method. http://serc.carleton.edu/econ/cases/what.html

33. Case studies. (2015). Retrieved from http://library.mines.edu/LIB-Research-Case-Studies

34. Teaching with case studies. (1994, Winter). Retrieved from http://www.stanford.edu/dept/CTL/cgibin/docs/newsletter/case_studies.pdf

35. Foulger, D. (2002, January 29). Fractally complex decision spaces and the efficacy of ethics instruction. Retrieved from http://davis.foulger.info/papers/fractallyComplexDecisionSpaces.htm

36. Schullery, N. (1999). Selecting workable cases for classroom use. Business Communication Quarterly, 62(4), 77-80.

37. Case studies. (2001). Retrieved from http://www.engr.psu.edu/ethics/casestudies.asp

38. Healy, T. (2014). Teaching ethics and teaching engineering - Some parallels. Retrieved from http://www.scu.edu/ethics/publications/submitted/healy/teachethics.html

39. Cooper, M., \& Bullard, L. G. (2014, Spring). Application of plagiarism screening software in the ChE curriculum. Chemical Engineering Education, 48(2), 90-106.

40. Narayanan, M. (2007). Assessment of ethics modules in an engineering curriculum. ASEE Annual Conference Proceedings. Retrieved from http://search.asee.org/search/f25202007Full14.pdf

41. The joy of being wanted. (n.d.). Retrieved from http://www.depts.ttu.edu/murdoughcenter/products/cases/case1003.doc

42. Davis, M. (2013). 7 step method for ethical decision making. Retrieved from http://ethics.iit.edu/IPRO/ 7stepmethod.pdf 
43. Davis, M. (2008). Format for ethical decision making. Retrieved from http://ethics.iit.edu/eb/Format for Ethical Decision Making.pdf

44. Davis, M., \& Weil, V. (2009). Ethics terminology and a format for ethical decision making. Retrieved from http://ethics.iit.edu/Ethics Terminology and Seven Steps.pdf

45. Ethics cases. (n.d.). Retrieved from http://www.depts.ttu.edu/murdoughcenter/products/cases.php

46. National Society of Professional Engineers. (2015). Board of ethical review. Retrieved from http://www.nspe.org/resources/ethics/board-ethical-review

47. Pritchard, M., ed. (2006). Teaching engineering ethics: A case study approach. Retrieved from http://www.onlineethics.org/Topics/ProfPractice/PPCases/csaindex.aspx

48. Lawlor, R. (2007, June). Moral theories in teaching applied ethics. Journal of Medical Ethics, 33(6), 370-372.

49. Wearne, P. (1999). Collapse: When buildings fall down. New York: TV Books.

50. Davis, M. (1991). Thinking like an engineer. Retrieved from http://ethics.iit.edu/publication/md_te.html 